\begin{tabular}{l|l|l|l} 
Received & Modification & Accepted & Published \\
\hline
\end{tabular}

\begin{tabular}{|c|c|c|c|c}
\hline $19 / 6 / 2021$ & --- & $21 / 06 / 2021$ & $10 / 9 / 2021$
\end{tabular}

Original Article

\title{
EFFECTIVENESS OF PLANNED TEACHING PROGRAMME ON KNOWLEDGE REGARDING CYBERCRIME AMONG HIGHER SECONDARY STUDENTS IN SELECTED SCHOOL \\ OF INDORE DISTRICT IN THE YEAR 2015-16 MRS.PRIYA PETER
}

Assistant Professor, Gayatri College Of Nursing, Udaipur

Corresponding email: priyapeter3245@gmail.com

\begin{abstract}
:
Introduction: Cyber crime is emerging as a serious threat in the World. Governments as well as police and intelligence departments have started to react. Indian police has initiated special cyber cells across the country and have started educating the peoples. Hence it is very important that students should have awareness among the cyber crime.

Methods \& Materials A Pre-experimental study one group pre-test and post-test design was adopted, the sample size was 50 higher secondary school students aging between 13-18 years and purposive sampling technique was used to collect the samples. Data collection was done by using researcher developed Structured knowledge questionnaire. The reliability of the tool was observed and reliability of the instrument was found $(\mathrm{r}=0.834)$

Result The findings showed the pre test mean of the samples was 8.82, and the post test mean was 19.4and the result of Paired ' $\mathrm{t}$ ' test which that was at $\mathrm{p}=0.05, \mathrm{t}_{49}=22.79$ (calculated value) which was higher than the tabulated value of ' $t$ ' $=1.6777$ which revealed that the planned teaching programme was effective. Significant association between birth order of child and pre test knowledge score was found at 0.05 level of significance.
\end{abstract}

Keywords Knowledge, Cybercrime, planned teaching, Effectiveness, Higher Secondary Students

Computer crime or cybercrimeis any crime that involves a computeror any electronic mean and a network. A crime committed or facilitated through the Internet is a cybercrime. Cybercrime is any criminal activityinvolving computers and networks. Netcrime is crim inherently a cybercrime. Children are highly vulnerable to cybercrime and this is an issue of serious concern. A newspaper article stated that in India $32 \%$ of the parents say that their children have had a negative experience online. These experiences include cyber bullying, eve teasing and child pornography. Children as young as 11 years are now on facebook, even though Facebook says that the social networking site is mean for 13 years and above. Children do not know how to use social media. They may unknowingly post compromising pictures of themselves, which then morphed and used to cyber bully them.

Even as cybercrime is growing in the country with most perpetrators being youngsters, there is a lack in cyber hygiene and netiquettes and this continues to be a major issue with schools and colleges across the country, said Rakshit Tandon, an Advisor Investigation Expert at the cybercrime unit of Uttar Pradesh police at Agra.

\section{STATEMENT OFTHE PROBLEM}

A Pre-Experimental study to assess the effectiveness of Planned Teaching Programme on knowledge regarding cybercrime among higher secondary students in a selected school of Indore district in the year 2015-16.

\section{OBJECTIVES OF THE STUDY}

1. To assess the Pre-test knowledge scores of higher secondary students regarding cybercrime.

2. To determine the effectiveness of planned teaching program on knowledge regarding cybercrime among higher secondary students.

3. To find out the association between pre-test knowledge score and selected socio-demographic variable regarding cybercrime among higher secondary students. 


\section{RESEARCH HYPOTHESIS}

1. H 1: There will be significant difference between the pre-test knowledge and post-test knowledge scores regarding cybercrime among higher Secondary Students

2. H 2: There will be significant association between pre-test knowledge scores and selected sociodemographic variable regarding cybercrime among higher secondary students .

\section{METHODS \& MATERIALS}

\section{Research Approach}

The research approach considered suitable for the present study was quantitative research approach.

\section{Research Design}

A Pre-experimental design (one group pretestposttest) was used to assess the effectiveness of planned teaching programme on knowledge regarding cybercrime among high school students.

\section{Population}

The population for the study was higher secondary school students aging between 13-18 years in the selected school of Indore district.

\section{Sample Size}

Sample size of 50 higher secondary school students aging between 13-18 yearsin the selected school of Indore district.

\section{Sampling Technique}

The sample selected through a purposive sampling technique.

\section{Sample Selection Criteria}

\section{Inclusion criteria}

Higher secondary students:

1. Aging between 13-18 years.

2. Who understand English and Hindi.

3. Who were willing to participate in the study.

4. Who were available at the time of the data collection.

\section{Exclusion criteria}

Higher secondary students:

1. Who are not willing to participate in the study.

2. Who cannot understand English and Hindi.

\section{Development of The Tool}

A structured knowledge questionnaire was developed for assessing the level of knowledge regarding cybercrime among higher secondary students. The investigator adoptedextensive review of literature, took opinion and suggestion take from experts., develop a blue print of the questionnaire, constructed demographic performa and questionnaire on knowledge regarding cybercrime, developed Planned teaching programme regarding cybercrime among higher secondary students in the development of the instruments.

\section{Description of thetool}

Structured questionnaire consists of the following parts:

Part I: Socio-Demographic variables

Part II: Structured knowledge questionnaire to assess the knowledge of higher secondary school students regarding cybercrime.

\section{Tool reliability}

The reliability of the instrument was analyze by using split half method by using Karl Pearson's product moment correlation formula. The reliability of the tool was observed and reliability of the instrument was found $(\mathrm{r}=0.834)$. Hence, the tool was reliable.

\section{RESULTS}

Section 1 :Description of Socio-Demographic variables of samples.

Majority of the samples belonged to 15-17 years $(60 \%)$, in which $(52 \%)$ of the samples were females. The data reveals that $(26 \%)$ of the samples study in class $11^{\text {th }}(20 \%)$. About $(46 \%)$ of the samples were youngerand majority of the samples $(70 \%)$ belonged to nuclear family.(40\%) of the sample belonged to upper middle class family. Majorityof the samples had no previous knowledge about cybercrime (86\%) and only (14\%) had knowledge about cybercrime through internet and through friends.

Section II: Pretest knowledge scores of higher secondary students regarding cybercrime

Thepretest level of knowledge scores of higher secondary students regarding cybercrime revealed thatmajority of the samples (74\%)had poor knowledge regarding cybercrime,samples $(22 \%)$ had good 
ISSN Print: 2581-8546 ISSN Online: 2582-2934

knowledge and only (4\%) had excellent knowledge regarding cybercrime.

Section III: Effectiveness of planned teaching programme on knowledge regarding cybercrimeamonghigher secondary school students.

The finding of the pretest mean was 8.82, and the post test mean was 19.4 and the result of Paired ' $t$ ' test( $\mathrm{p}=0.05, \mathrm{t}_{49}=22.79$ ) was higher than the tabulated value $(\mathrm{t}=1.6777)$ which revealed that the planned teaching programme was effective and $\mathrm{H}_{1}$ research hypothesis was accepted as there is significant difference between the pre test and post test knowledge score regarding cybercrime among higher secondary school students.

\begin{tabular}{|l|l|l|l|}
\hline Item & Sum & Mean & Standard deviation \\
\hline $\begin{array}{l}\text { Total Pre test } \\
\text { score }\end{array}$ & 441 & 8.82 & 0.4233 \\
\hline $\begin{array}{l}\text { Total Post test } \\
\text { score }\end{array}$ & 970 & 19.4 & 0.6228 \\
\hline
\end{tabular}

\begin{tabular}{|l|l|l|l|c|l|}
\hline- & Mean & $\begin{array}{l}\text { Standard } \\
\text { deviation }\end{array}$ & $\begin{array}{l}\text { Calculated 't' } \\
\text { value }\end{array}$ & DF & $\begin{array}{l}\text { Tabulated } \\
\text { 't' value at } \\
5 \%\end{array}$ \\
\hline $\begin{array}{l}\text { Paired pre- } \\
\text { test and } \\
\text { post test } \\
\text { knowledge } \\
\text { scores }\end{array}$ & 10.58 & 3.282 & 22.793 & 49 & $\begin{array}{l}\text { At } \mathrm{p}=0.05, \\
\mathrm{t}=(1.677)\end{array}$ \\
\hline
\end{tabular}

Section IV: Association between pretest knowledge score regarding cybercrime among higher secondary students and socio-demographic variable.

Out of 7 socio-demographic variable one of them shows significant association that was association between Birth order of child and pre test knowledge score.The result was at $5 \%$ level of significance $\left(p=0.05 x^{2}=9.49\right)$, the calculated value of $x^{2}=30.34$ was greater than the tabulated value which shows that there is significant association between birth order of child and pre-test knowledge score. Hence, research hypothesis $\mathrm{H}_{2}$ was accepted.

\begin{tabular}{|l|l|l|l|l|}
\hline $\begin{array}{l}\text { Selected } \\
\text { demographic } \\
\text { variable }\end{array}$ & DF & Table value & $\begin{array}{l}\text { Calculated } \\
X^{2} \text { value } \\
\text { At }=0.05\end{array}$ & $\begin{array}{l}\text { Level of } \\
\text { significance }\end{array}$ \\
\hline Age & 4 & 9.49 & 2.341 & N.S \\
\hline Gender & 2 & 5.99 & 2.687 & N.S \\
\hline Education & 8 & 15.51 & 11.537 & N.S \\
\hline $\begin{array}{l}\text { Birth order of } \\
\text { child }\end{array}$ & 4 & 9.49 & 30.34 & S* \\
\hline Family type & 4 & 9.49 & 1.078 & N.S \\
\hline Family status & 6 & 12.59 & 7.018 & N.S \\
\hline $\begin{array}{l}\text { Previous } \\
\text { knowledge }\end{array}$ & 4 & 9.49 & 4.278 & N.S \\
\hline
\end{tabular}

\section{DISCUSSION}

Objective

1 To assess the pre-test knowledge scores of higher secondary school students regarding cybercrime. The study states that samples had poor knowledge(74\%)regarding cybercrime which is supported by a study conducted by Young Soo Loo (2014) on the awareness of invasion of privacy on social networking site among youth age group between 18-24. Objective

2 To determine the effectiveness of planned teaching programme on knowledge regarding cybercrime among higher secondary school students. The findings showed the pre test mean of the samples was 8.82 ,and the post test mean was 19.4and the result of Paired ' $t$ ' test which that was at $\mathrm{p}=0.05, \mathrm{t} 49=22.79$ (calculated value) which was higher than the tabulated value of ' $t$ ' $=1.6777$ which revealed that the planned teaching programme was effective and is supported by a study conducted by Schilder. D. Jannake (2012) on the effectiveness of an intervention to promote awareness and reduce online risk behavior in adolescence on two groups (control and experimental) Objective

3 To find out the association between pre test knowledge score and selected demographic variable regarding cybercrime among higher secondary students. One of the sociodemographic variable shows significant association that was association between Birth order of child and pre test knowledge score. The result was at $5 \%$ level of significance $(p=0.05)$ the calculated value of $\mathrm{x} 2=30.34$ which was 
greater than the tabulated value. The study is supported by another study conducted by Herath Tejaswini (2008) that revealed that gender is found to be positively associated with vulnerability $(\mathrm{x} 2=6.72, \mathrm{p}=0.05)$ indicating female gender. CONCLUSION The findings of mean (post test 19.4) and Paired't' test $(p=0.05, t 49=22.79)$ reveals effectiveness of planned teaching programme regarding cybercrime among higher secondary students and association between pre- test knowledge score and socio-demographic variables was significant in the study.

\section{REFERENCES}

1. JainAtul (2004). Cybercrime Issues, threats and Management (2ndedition), Sage publication. 72114

2. K. Baun, M.Catalano S Rand \& K Rose (2009). Stalking Victimization in the United States Bureau of Justice Statistics, US department of Justice. 29-78

3. JohnBest .W., Kahn V. James. Research in education.(10th edition),Person publications. $61-80$

4. S Brenner (2011). Defining Cybercrime A Review of Federal and state Law. 15-10
5. J Cassell., Huffaker, D., Tversky, D., \& Ferriman, K. (2006). The language of online leadership: Gender and youth engagement on the Internet. Applied Developmental Psychology, 42, 436-449

6. Avais Abdullah Muhammad (2014). Awareness regarding cyber victimization among students of university of Sindh Jamshoro. International Journal of Asian social science. Vol 4(5),pp 632641.

7. Bergen Emilia (2013). Adults sexual interest in children and adolescent online: a quasiexperimental study. International journal of cyber-criminology. Vol 7(2), pp94-111.

8. Sourander (2010). Middle School students perception and responses to cyberbullying. Journal of Educational computing research 46 (4).pp 395-413

9. IC3 (2010). Internet Crime Report. Retrived October 1, 2011, from the Internet Crime C o m p l a n t C e n t e r. http://www.ic3.gov/media/2011/110224.aspx 10. Koovaski dineshan (2010). Internet abuse among the adolescents: a study on the locale factor. Retrieved from http://statcan.gc.ca /pub/85-558-x/85-558-x2002001-eng.pdf 